\title{
US-TALIBAN PEACE TALKS: CHALLENGES AND OPPORTUNITIES
}

Mian Muhammad Azhar ${ }^{1 *}$, Muhammad Waris ${ }^{2}$, Ali Shan Shah $^{3}$, Abdul Basit ${ }^{4}$, Zil-i-Huma Rafique ${ }^{5}$

${ }^{1 * 3,4}$ Assistant Professor, Department of Political Science \& IR, Government College University Faisalabad, Pakistan;

${ }^{2,5}$ Assistant Professor, Department of History \& Pak. Studies, Government College University Faisalabad, Pakistan.

Email: *muhammad.azhar@gcuf.edu.pk

Article History: Received on $20^{\text {th }}$ January 2021, Revised on $7^{\text {th }}$ April 2021, Published on $13^{\text {th }}$ April 2021

Abstract

Purpose: The study explores the after-effects of US-Taliban peace talks and how these can bring peace in decades' long warwracked Afghanistan. It also investigates whether or not the ever-widening trust deficit between the stakeholders be bridged through these talks and in the future, Afghan soil will never be used for transnational activities. How can these talks neutralize and influence militant groups to join mainstream politics?

Methodology: Relevant data were collected from newspaper articles, editorials, websites, journals, research reports, and magazines and minutely analyzed. The research is qualitative and explanatory cum exploratory in nature. Analytical techniques were utilized to evaluate data on the outcomes of the Doha-based US-Taliban peace talks.

Main Findings: The study finds that it's easy to conclude table talks but hard to implement on the ground. Decades' long trust deficit will not come to an end until and unless all the stakeholders move forward positively. Intra-Afghan dialogue is the most important step to bring the political instability to an end and constitutional accommodation be made accordingly to space all these in mainstream politics.

Applications: Findings of the study, to some extent, will be fruitful for the stakeholders to prioritize the steps to bring peace to Afghanistan. It also cautions regional and international actors to pursue their interests without using the soil of Afghanistan for seditious activities in rival countries.

Novelty: The study is unique in the sense that it explores the ways and means through which decades' long trust deficit can be bridged by looping into the stakeholders for lasting peace to Afghanistan and the region.

Keywords: Peace Talks, Militancy, Mainstreaming, Regional Actors, Withdrawal.

\section{INTRODUCTION}

The twin towers incident forced the world community to revisit their policies regarding the potential threat of militancy and it developed a consensus to curtail terrorist activities that were increasing across the globe. Afghanistan became the centre of concern especially for the US and generally for the whole world (Kendall, 2002). The world community demanded the Mullah Umar-led Taliban government to cut its ties with Al-Qaeda operatives and hand them over to the US. The refusal of the Taliban to do this caused the US and its allies to attack Afghanistan according to its program of "war on terror" that it had launched and it had the support of the UNO. The war against terrorism became more complicated over time. The US and its allies suffered heavy losses in terms of human lives. Nonetheless, the US claimed that it had succeeded in saving the world community from the menace of terrorism and had wiped out all the major terrorist organizations and their operatives especially in Afghanistan and generally around the world (Sales, 2019). Furthermore, Al-Qaeda had been dismembered and its major activists had either been captured or killed. However, after spending billions of dollars and causing dire collateral damage the US claim seemed to be unproven. Despite NATO military presence militants struck when and where they wanted. There were even strikes in Kabul, which was heavily guarded it was a primary target of the Taliban and there were innumerable suicide attacks and gun battles there (Thomas, 2019; Shinn \& Dobbins, 2019). In 2018 the civilian death toll in Afghanistan was the highest in the long-running war. Although the collateral damage was the result of action by both the pro-government and anti-government forces how the militants challenged the might of the NATO troops and incumbent government was very detrimental to the US cause in Afghanistan (Afghanistan: Civilian deaths at record high in 2018 - UN, 2019).

The war that had been started by the US and its allies, and that the whole world had supported as a bid to eradicate terrorism began to get criticized because of the massive civilian causalities due to NATO aerial bombing, ground strikes, and retaliatory attacks by the Taliban (Malkasian, 2020).

Getting involved in a long-term engagement in Afghanistan was against US interests. Previous presidents of the US-made commitments to withdraw troops from Afghanistan but were unable to do so. They entered into three-way negotiations with the Taliban and the Afghanistan government, but these talks didn't make any headway.

Thereafter, Trump's victory in the US election and the rational approach he adopted to end the long-running Afghan war forced the policymakers to initiate new negotiations with the Afghan Taliban (Vestenskov \& Hasan, 2018). 
In July 2018, the Trump administration decided to have direct talks with the Taliban taking regional and non-regional actors on the board. However, it was quite astonishing that the US decided not to include the Afghan government in these negotiations. The US move represented a dramatic reversal in the policy it had previously been following, which advocated an 'Afghan-led, Afghan-owned peace process (Thomas, Afghanistan: Background and US Policy, in Brief, 2019). In September 2018, Mike Pompeo, Secretary of the State, appointed former US ambassador Zalmay Khalilzad as a special representative for Afghanistan reconciliation. Since then Khalilzad has met several times with the representatives of the Taliban in Doha and shuttled between Pakistan and other states (Interpreting the U.S. Talks with the Taliban, 2019).

This research explores the ways and means through which decades' long trust deficit can be bridged by looping into the stakeholders. The study also discusses in detail the humps and bumps heading on the way. More specifically, the study answers the following questions.

RQ1: Whether the ongoing peace talks would bring concrete results and the decades-long mistrust among the parties be bridged?

RQ2: Whether or not the incumbent Afghan government would support the peace talks and if the intra-Afghan dialogue would lead to a conclusive end of the conflict?

\section{REVIEW OF LITERATURE}

Tariq in his article discusses the US-Taliban peace talks in the context of the Intra-Afghan peace talks. The writer enlists the reasons including Increasing violence, deadliest attacks resulting the hundreds of causalities, worsening law and order situation, and financial constraints which forced the US and allies to have a negotiation with the Taliban. He also discusses the causes and consequences of the exclusion of the Afghan government from the Doha peace talks. It was quite flimsy that the US administration signed a peace deal with the Taliban whom it blamed for transnational terrorist activities for decades. $\mathrm{He}$ also highlights the role of Pakistan in bringing the US and Taliban to a table. However, the writer believes that it would be difficult to execute the peace deal in true letter and spirit as the stakeholders did nothing to en loop Afghan government and Afghan warlords. The writer in this article attempts to cover the majority of the issues which can choke and strike down the peace deal. However, he did not analyze the role of regional and international actors in maturing the peace deal (Tariq, 2002).

Farr in this article sheds doubts over the implementation of the US-Taliban Doha Peace deal. He believes that the exclusion of the Afghan government from the peace talks over the insistence of the Taliban will become the biggest hurdle in the implementation of the peace accord. Farr believes that the Taliban is a divided house with political leadership signing the peace accord and the militant commander in the field may not own the accord. Operating all things in a settled way will become difficult as stakeholders may not bridge the gap in a short period. This article encompasses multiple factors relating to the Doha peace talks but missed the importance of intra-Afghan dialogue whose outcome can change the scenario (Farr, 2020).

Bew et al, elaborate on the historical background of the Soviet Union's experience of negotiation with the Taliban and the evolution of US-Taliban negotiation since 2001. The report explores the causes and consequences of the failure of early dialogues. Writers believe that talking to the Taliban was never likely to be the "silver bullet". The report expresses considerations over the process and mechanism of US-Taliban negotiation and articulates small chances of success. The whole process of talks has been characterized by the anarchy of good intentions. Writers in this report focus on the expectations rather than hope and misjudged the Taliban's approach of pragmatism (Bew, Evan, Frampton, Porges, \& Neumann, 2013).

Khan in this article articulates the factors hampering the peace process in Karazai's consecutive tenures. She concludes that the dual policy of pursuing negotiation on one hand and gearing up military operation on other hand widened the existing trust deficit and all initiatives to bring peace in Afghanistan met to an ill end. However, the National Unity Government (NUG) under Ashraf Ghani's presidency made several attempts to bridge the gap and tried to reconcile with the Taliban. The writer also loops into the supportive role of both Pakistan and China. She emphasized the importance of the Taliban-Afghan government to marginalize the emerging threat of ISIS. However, the article seems to miss the importance of intra-Afghan dialogue and the role of international actors to bring sustainable peace in Afghanistan (Khan, 2016).

Codesman in this report en loops the factors hampering the peace deal to be executed in Afghanistan. He alleges that the Taliban are seeking more time to control the more area and developing pressure over the Afghan government through consistent strikes over urban centres where the Afghan government claims to be more effective. He also criticizes the way and means through which the US administration did a deal with the Taliban keeping the Afghan government away from the whole exercise. Lack of coordination and to some extent "trust" among stakeholders has become an impassable obstacle yet. Although some cosmetic measures have been taken to en route the peace accord, however, it requires some concrete and solid measures to bridge the gap (Cordesman, 2020). 
Kazmi in this article stresses dealing with anti dialogue forces in Afghanistan in a proper way. Without convincing them any attempt to bring peace in Afghanistan will be choked and hampered. Bringing them on the board has become the prerequisite of the peace process. The author also highlights the role of Pakistan in bringing stakeholders to a table to close the lengthy chapter of the war. However, it requires political will to cultivate trust (Kazmi, 2015).

The writer advocates that intra afghan dialogue is a key component of bringing peace in Afghanistan. Doha peace accord cannot bring peace to Afghanistan if the International community fails to broker the intra afghan dialogue. For the last eighteen years, the world has accessed that war had become an unwinnable and lasting peace that will prevail through dialogue among stakeholders ( Jami, 2020).

The writers point out the ever-widening trust deficit among the stakeholders and argue that without bridging this, a viable solution seems to be a myth. The research stresses that Pakistan can and should play a facilitating role to bring stakeholders to a negotiation table. It would not only be helpful for Pakistan to improve its security and stabilize its ailing economy but regional states will also reap benefits from peaceful Afghanistan (Idrees, Rehman, \& Naazer, 2020).

The research concludes that the US-Taliban peace accord seems to be charming and catchy in papers but its implementation on the ground seems to be a tough job. Decades' long enmity will take time to be ended and stakeholders must show positivity in their words and actions. It's a long bumpy and humpy road ahead to achieve the goal (United States Signs Agreement with the Taliban, but Prospects for its implementation Remain Uncertain, 2020).

Shinwari sums up the failures and shortcomings of US-Taliban Peace talks and alleges that the US attempts to have direct negotiation with the Taliban were foiled by Pakistan's military and intelligence agencies. The writer concludes that Taliban leadership seems to be inefficient and incompetent to strike a deal with the US due to over-influence from Pakistan's agencies (Shinwari, 2019).

Pandey and Sareen shadows over the prospects of the US_taliban peace talks and of the opinion that it seems less than promising as the stakeholders remain divided over the procedural issue. Moreover, the vested interests of regional and international players may lead to the perpetuation of war rather than lasting peace. Enduring peace requires a broadband dialogue among stakeholders (Pandey \& Sareen, 2020).

The writers analyzing contextually say that humanitarian, socio-economic and political dimensions have made Afghan conflict precarious for civilians. The report discusses in detail interrelated and interdependent regional and international community interests which are fuelling up the conflict and provide the way out to marginalize the widening damages of the decades' long war. Authors opine that controversial presidential elections and exclusive peace talks will be another major setback for Afghan communities and lasting peace for the country (Tronc \& Nahikian, 2018).

Moona Kanwal Sheikh and Amina khan believe that peace in Afghanistan is linked with the withdrawal of US forces, stopping all targeted military operations against the Taliban, and downscaling undue support to the government. International actors should sense the emerging threat of ISKP and come forward to play a constructive role to end the decades' long war (Sheikh \& Khan, Prospects of Settlement with the Afghan Taliban Exit, Peace and Governance from the Taliban Perspective, 2019).

Moona Kanwal Sheikh \& Maja Touzari Janesdatter Greenwood summarise the attempts, efforts, and outcomes of the USTaliban talks and stress over the comprehensive dialogue engaging all the stakeholders. US administration, Karzai-led government, and Taliban should take necessary steps to bridge the gap to make the dialogue productive and result-oriented. International media should also play a constructive and supportive role accordingly (Sheikh \& Greenwood, 2013).

Miller and Blake analyze in detail the US-Taliban peace process and of the opinion that in-depth policy has not been formulated and potential obstacles will be ahead to implement the dialogue outcomes. The report stresses a substantive peace agreement rather than a roadmap engaging internal and external actors. A proper mechanism should be drafted to marginalize the role of spoilers and there should be necessary security arrangements during the transitional period (Miller \& Blake, 2019).

\section{RESEARCH METHODOLOGY}

To find out the answers to the designated research questions, available secondary resources were searched for and obtained during the instant study. Relevant data were collected from newspaper articles, editorials, websites, journals, and magazines and minutely analyzed. The research is qualitative and explanatory cum exploratory in nature. Analytical techniques were utilized to evaluate data on the outcomes of the Doha-based US-Taliban peace talks. During the course of the research, the response of all the stakeholders including the Afghan government, ethno-regional and regional entities, and the roles of international actors and their participation were examined. 


\section{RESULTS AND DISCUSSION}

The prospects of the ongoing peace talks are still unclear. Major obstacles are still in the way. Stakeholders should face critical issues including the decades-long trust deficit, political instability, ceasefire, and economic weakness.

\section{Political instability}

Increasing political fragmentation along ethnic lines and warlords gaining a greater hold has put Afghanistan's political stability at stake. Moreover, regional political differences have had made the existing political system of Afghanistan more volatile. The decades-long uncertain and unsettled Afghan politics will affect the positive outcome of the ongoing peace talks (Khattak Z. U., 2018). The Ghani-Abdullah political cum government partnership has since completed its tenure under the control and command of the US since the settlement was brokered by the US administration the purpose of which was to mitigate the ethnic and regional fragmentation in the country. The US was so keen to implement this policy that its nationbuilding credibility in Afghanistan was questioned because of the contentious and controversial 2014 election results (Schmeidl, 2016). However, despite the tenure of this government the ethnic divisions and differences still exist to their full extent and have the potential to cause political upheavals in the future (Kaura, 2018).

The parliamentary elections in Afghanistan were scheduled to be conducted in October 2018 but were marred by 'logistical', 'administrative' and 'security problems' (Afghanistan Pledges October date for the parliamentary election, 2018; Afghanistan: Background and U.S. Policy, in Brief, 2019). Although the new parliament started functioning in April 2019, but the all-important presidential election was postponed twice till September 2019. Subsequently, Ashraf Ghani was reelected, and when Abdullah Abdullah refused to accept the results a power-sharing deal was brokered in May 2020 between the two rivals (Afghanistan Presidential Rivals Strike Power-sharing Deal to End Standoff, 2020; Mashal, 2020). In retrospect, it is unclear whether these postponements were related to the ongoing peace talks or some clandestine 'administrative' issues. The US has denied the probability of any interim government accommodating the Taliban representatives. However, there are some speculations that such an arrangement and settlement might be necessary to bring the Taliban into mainstream politics and the decision-making process (Thomas, Afghanistan: Background and US Policy, in Brief, 2019). The possibility of such a proposition would depend upon the outcome of the ongoing peace talks. The Taliban might have some proposals that they have mentioned during the negotiations with Khalilzad, but still, both sides are avoiding giving any comment on the probability of an interim setup.

\section{Intra-Afghan dialogue}

Afghanistan is a fragmented and diverse country. The socio-political division lies along ethnic and regional lines. The major ethnic group is the Pashtun, then there are the Tajiks, the Uzbeks, and the Hazarawals. The ethnic-regional actors backed by equipped militias have been enjoying socio-political monopoly as well as the capacity to win elections in their territory for a long time. Their vested interests dominate the administration and politics of Afghan society. Afghanistan's internal political and security instability is due to the adventures of these entities to gain socio-political supremacy (Sheikh \& Greenwood, 2013).

Initially in the ongoing US-Taliban peace talks the US declined to take the incumbent Afghan government on board and on the other hand, the Taliban had already shown their animosity towards the out-going Afghan government and strongly declined to be engaged in talks with it (Thomas, 2019; Shinn \& Dobbins, 2019). However, some circles believe that excluding the Afghan national government from the peace talks will adversely affect the outcome of the negotiations. President Ashraf Ghani has warned that 'No agreement to end the 18-years conflict in his country could be reached without his government's active involvement (Khattak D., 2019; Constable, Ryan, \& Sonne, 2019). Moreover, sidelining Ghani from the talks would affect his legitimacy and political stature which would undermine the already somewhat tenuous authority of the government. The decades-long trust deficit, ideological differences, divergent political approaches, and the 'legitimacy' of the incumbent government have been the factors that have created a rift between the Taliban and the Afghan government. The Taliban believe and assert that the Afghan government is nothing but the 'puppets of the USA' (Interpreting the U.S. Talks with the Taliban, 2019 \& Thomas, 2019). On the other hand, the Afghan government maintains that the Taliban are only a 'militia', perpetrating terrorist activities to destabilize the government and have no role in the political and electoral arena. That is why the previously planned meetings between Taliban and Afghan representatives collapsed and multiple objections were raised by the Taliban, including objections to the size of the Afghan delegation; its official status, and the venue of the meetings (Shams, 2019). Nonetheless, it is crystal clear that talks without taking the intra-Afghan stakeholders on the board would be fruitless. Hence, sensing the complexity and the importance of the intra-Afghan groups, the Taliban and the US showed their flexibility and willingness to have talks with the Afghan government (Azami, Afghanistan war: What could peace look like? 2019).

It is clear that multi-party negotiations (with the US, Taliban, Afghan government representatives, and regional stakeholders) are necessary to settle the modalities of a power-sharing arrangement; make possible and workable modifications and 
amendments to the existing constitution (Their, 2019); an array of structural and administrative changes that are required; formulate social norms and the viability of sharia law (Hossaini, 2020). Moreover, Kabul's over-centralized system of government needs some improvements and decentralization may generate some space for those who feel excluded or inferior (Hussain, 2019). Discussions on economic development and infrastructure revamping might take reasonable space during the talks. On the other hand, America's main objective in these negotiations is to create a stable and peaceful Afghanistan that neither hosts nor collaborates with transnational terrorists and terrorist organizations (Azami, Afghanistan war: What could peace look like? 2019). The US wants to confirm guarantees from the stakeholders that the soil of Afghanistan will never be used against the peace and stability of the world community and especially the US. Further that the Afghani representatives would stress upon making workable and effective arrangements to strengthen war-wracked Afghanistan politically and economically (Interpreting the U.S. Talks with the Taliban, 2019; Thomas, 2019; Shinn \& Dobbins, 2019; Shams, 2019).

The more flexibility the stakeholders show during the negotiations the more result-oriented and fruitful the talks will become. Otherwise, the chances of a positive and desirous outcome will be bleak and doubtful.

It is pertinent to mention that the stakeholders are showing flexibility, willingness to accept solutions, and desire to arrive at a conclusion that will bring an end to the long-standing intra-Afghan conflict and decades-long war which has resulted in thousands of lives and billions of dollars (Shinn \& Dobbins, 2019).

\section{Afghan security}

Despite advanced technologically equipped NATO forces (RSM \& OFS) and the NATO-trained Afghanistan National Defense Security Forces (ANDSF), the territorial grip of the Kabul government on its far-reaching provinces in the South and East is becoming weaker. The Taliban are tactfully and steadily increasing their influence and territorial grip across the board. The Special Inspector General for Afghanistan Reconstruction (SIGAR) in his January 2019 report disclosed that the share of the districts under government control or influence fell to 53.8\% as of October 2018. The report marks the lowest point of the government's territorial control since the SIGAR started tracking such information in November 2015. The report shows that $12 \%$ of the districts are under insurgent control or influence, with the remaining $34 \%$ contested (Thomas, Afghanistan: Background and US Policy, in Brief, 2019).

The ongoing uncertain law and order situation in Afghanistan, especially since 2018, showed that the Taliban has retained the ability to conduct high-profile attacks, when and where they want. They have the organization to demonstrate their militia capabilities and gain control of territory. Recently, fatalities that ANDSF had to face are nothing less than 30-40 per month. In January 2019 President Ghani stated that 45000 security personnel have sacrificed their lives since he took the office in September 2014 (Afghanistan's Ghani says 45,000 security personnel killed since 2014, 2019). Interestingly, though they are protected by high fences and other safeguards and also being well-equipped the US-led coalition troops are not safe from the sporadic attacks of the Taliban as well. In October 2018, the Taliban blew up the compound of the governor of Kandahar when General Miller was present there. However, he remained safe but a general who was accompanying him got wounded and a prominent police chief Abdul Raziq lost his life along with a number of other provincial officials (Constable \& Salahuddin, U.S. commander in Afghanistan survives deadly attack at governor's compound that kills top Afghan police general, 2018).

Apart from the Taliban, local Islamic State militants are becoming another emerging threat to internal peace in Afghanistan (Johnson, 2016). The US troops are making attempts to nip the evil in the bud. However, the affiliates of the Islamic StateKhorasan Province (ISKP or ISIS-K) have shown their presence and pose a threat to the region. ISKP and the Taliban forces have sometimes fought each other over control of territory or because of political or other differences (Jadoon, Jahanbani, \& Willis, 2018; Rahim \& Nordland, 2018). The US claims that fleeing Iraqi and Syrian ISIS fighters are assembling in Afghanistan and making attempts to gain control of territory and the population in some places. On the other hand, the ISKP also has claimed responsibility for several large-scale attacks, many targeting Afghanistan's Shia minority, the Hazarawals. The UN reports that while facing adverse propaganda and competition from local militant groups the ISKP, 'remains a longterm threat' (Twenty-second report of the Analytical Support and Sanctions Monitoring Team submitted pursuant to resolution 2368 (2017) concerning ISIL (Da'esh), Al-Qaida, and associated individuals and entities, 2018).

Despite spending billions of dollars to train and equip the ANDSF, the law and order situation in Afghanistan is not improving. People and property are not safe. The crime rate has been accelerating and the drug mafia expanding its operations even in the presence of thousands of NATO troops (Felbab, 2016). The US administration does not see how the Afghan government will be able to maintain internal security after the withdrawal of NATO troops and foresee turmoil in Afghanistan. The US negotiator wants to get maximum guarantees from the Taliban and other militia groups to avoid internal conflicts in the future and thereby provide NATO troops a safe exit. However, the mechanism to ensure such a proposition is still unresolved (Thomas, 2019; Shinn \& Dobbins, 2019). Neighboring states, including Iran and Pakistan, have already shown their concern about the inability of the ANDSF to control law and order especially after the withdrawal of NATO troops and the 'expected' insurgency that will ensue (Khattak Z. U., 2018). The view of some experts is that it all 
depends on how the Taliban and the US succeed in engaging Intra-Afghan groups in the peace process and how the new constitutional setup is devised. It is important to accommodate all the intra-afghan stakeholders in whatever political cum administrative setup is devised in the future. If the negotiators succeed in taking all the significant concerned groups on board then the outcome is likely to be more suitable for the US and all the stakeholders and hopefully, long war-wracked Afghanistan may become a haven of peace and prosperity.

\section{Ceasefire}

Although the US and Taliban are engaged in peace talks in Doha but intense fighting continues across the country. The USled coalition forces are conducting frequent airstrikes targeting the militants' hideouts and on the other hand, the Taliban and other militant groups are fighting to gain maximum territorial control. As a result, more civilian causalities are being recorded in recent months as compared to that during the earlier period. 2018 was the worst year so far in this regard. There were more than four thousand civilian casualties recorded, $11 \%$ more than the previous year. Ironically, airstrikes are killing more civilians than militants. However, despite all these efforts Kabul has not been able to extend administrative control over the far-flung areas of Afghanistan. In fact, the central government is losing its grip over the territory of Afghanistan at an increasing rate and the Taliban are occupying more areas and making their influence more effective. It is quite alarming to learn that these militant groups have succeeded in gaining control over more Afghan territory than at any point since the US invasion in 2001 (Qazi, US-Taliban talks for peace in Afghanistan: What we know so far, 2019).

The US wants to strengthen its position on the peace-talk table and hence is conducting a greater number of strikes to try to weaken the Taliban and other militant groups. On the other hand, the Taliban is also tactfully enhancing its power and trying to increase its territorial control to maximize its leverage on the negotiating table. Furthermore, the Taliban political wing is under severe pressure from their military commanders not to agree to a ceasefire before achieving a tangible goal (Qazi, 'Peace deal is near': What we know so far about US-Taliban talks, 2019). They had vociferously demanded that there would be no ceasefire till there was the complete withdrawal of NATO troops from Afghanistan. The Taliban also rejected the ceasefire call issued by the Loya Jirga (grand council of chiefs) during the holy month of Ramadan saying, 'Waging war during Ramadan had even more rewards' (Azami, Afghanistan war: What could peace look like?, 2019).

The ongoing situation is critical and might become the main obstacle in reaching an agreement in the Doha peace talks. Any peace agreement without a permanent ceasefire would jeopardize the future peace of Afghanistan. All the stakeholders including the USA, Taliban, the Kabul government, and regional actors should play a constructive role and take effective steps to declare a permanent ceasefire in order to put the peace talks on track.

\section{International and Regional Actors}

Afghanistan has become the battleground of regional and international players. They have their own strategic interests and are pursuing their vested interests both covertly and overtly. They are facilitating the local ethno-regional actors in terms of finance and weapons to strengthen their presence at the cost of peace and stability in Afghanistan. These regional and international players are playing a pernicious and destructive game by pursuing their rivalries availing the soil of Afghanistan (Thomas, Afghanistan: Background and US Policy in Brief, 2019). Pakistan supported the Taliban while India supported the Northern alliance for their own vested interest. Presently, India is investing billions of dollars in Afghanistan to establish itself as a regional power by developing and building infrastructure there. India is playing its cards tactfully and is interested to fill the security vacuum that will be created by the withdrawal of the US-led coalition troops from Afghanistan (Chaudhuri \& Shende, 2020); (Chalk, 2012). India is assiduously proclaiming on all international platforms that Pakistan is to blame for militancy and providing military training, arming, and patronizing the Taliban (Robin, 2002). On the other hand, Pakistan blames India for using Afghan soil against Pakistan and claims that India is providing financial and diplomatic support to anti-Pakistan groups and training them militarily to undermine the peace and security of Pakistan (Khattak Z. U., 2018). Moreover, India is using Afghan soil to sabotage the ongoing mega projects under the China-Pakistan Economic Corridor especially in Baluchistan (India using Afghan soil for terrorism in Balochistan, says Interior Minister, 2017).

Iran is taking a keen interest in the internal issues of Afghanistan due to its proximity to Afghanistan and strategic interests. Because of its religious ideology, Iran wants a pro-Shia government in Kabul and is utilizing its resources to minimize the Pashtun influence in intra-Afghan politics. Hence, Iran and India are both engaged in limiting the role of Pakistan in Afghanistan. Iran and India share the view that the reemergence of the Taliban will adversely affect their respective interests. That is why, both are investing heavily to support the anti-Pashtun and anti-Taliban groups in Afghanistan (Khattak Z. U., 2018).

Moscow is also concerned due to the precarious security situation in Afghanistan and the geo-economical and geopolitical challenges to the region the conflict there presents and considers the ongoing instability a major threat for Russia. They perceive the presence of IS activists and militia there will disrupt the peace of the region if they succeed in making a base in 
Afghanistan. Putin considers that 'the IS (Islamic State) presence in Afghanistan is a threat and security challenge to the interests of his country. On the other hand, Moscow is interested in making it difficult for the US forces engaged in Afghanistan and hence is covertly providing support to anti-USA militant groups (Azami, Is Russia arming the Afghan Taliban, 2018; Wahdatyar, 2017).

Washington is planning 'a safe exit' from Afghanistan but it is still interested in prolonging its influence in that country to maintain its hegemony there. It is trying to bring the ongoing instability in Afghanistan under control. Moreover, the US is intent on countering the increasing interests of China, Russia, and Iran there. The US administration is applying a multidimensional strategy, trying to consolidate its own interests and at the same time undermining the BRI project. Moreover, Washington wants to ensure that the government in Kabul should be pro-US and there should be nothing that could challenge the US interests there (Mashal, Taliban and U.S. Strike Deal to Withdraw American Troops From Afghanistan, 2020). Russia and Iran don't want the US to prolong its stay in Afghanistan because they feel it is an obstacle and jeopardizes their interests. Indian's increasing influence in Afghanistan has become a threat to the peace and stability of Pakistan. Furthermore, India does not want the reemergence of a Taliban government in Kabul and hence it is providing support to anti-Taliban groups. The vested interests of these regional and international players have made the situation in Afghanistan more complex and difficult to resolve. However, lasting peace in Afghanistan depends upon the role of all these actors. Without taking them on board, a positive outcome of the ongoing peace process seems to be difficult (Khattak Z. U., 2018; Kaura, 2018).

\section{Opportunities}

Apparently, both the US and the Taliban are moving closer to reach a peace deal. The world and media are closely following each step of the process. If the situation remains on track and all the stakeholders succeeded in signing an agreement it will not only bring peace and stability to Afghanistan but the world community will benefit from the end of this decades-long conflict.

\section{Regional economic stability}

Since the last two decades, the Afghanistan has become the battleground for numerous regional and extra-regional actors to achieve their goals. The US-led NATO forces claim to have gained maximum achievements and succeeded in eradicating Al-Qaeda and other militant groups from Afghanistan, but on the other side, the Taliban has limited the writ of the government practically to only Kabul and its administrative and governmental control in the far-flung regions is challenged by the Taliban when and where they wanted. Warlords control many other regions. Though they may be affiliated with the government they remain basically independent entities. The dreadful Afghan war has resulted in crippling infrastructural and economic destruction along with causing socio-political fragmentation. Not only Afghanistan but neighboring states have suffered considerable loss of lives and economic setbacks. Without peace in Afghanistan, regional economic stability and connectivity have become a nightmare (Ahmadzai, 2017; Haidari, 2017).

After 9/11, China evaded becoming part of the war against terror and remained neutral until 2005. In 2006, China signed a treaty of 'Friendship, Cooperation and Good Neighborly Relations' with the Kabul government. Due to its proximity Afghanistan has a direct influence on the security of China. In 2013, China envisioned the 'One Belt One Road (OBOR)' program and launched the China-Pakistan Economic Corridor (CPEC) as a flagship project. China wants to connect Central Asia with South Asia for maximum utilization of natural resources of the concerned nations for the socio-economic uplift of the masses. The designated scope of this program will become more effective if there is a strong government and sustainable peace in Afghanistan (Khattak Z. U., 2018).

On the other hand, India is investing billions of dollars in Chahbahar port in Iran to access the natural resources of Afghanistan and Central Asia. The proposed tri-nation arrangement of India, Iran, and Afghanistan will be more effective if the conflict ends and there is stability in Afghanistan. Through Chahbahar, Afghanistan will be able to access mercantile trade routes for its natural resources and gain economically.

\section{Regional Peace and stability}

The ongoing US-Taliban peace talks are moving onwards evoking both optimism and pessimism. The hopeful scenario is that the talks will achieve optimum success and arrive at an agreement that will bring stability, peace, and tolerance and will lead to the end of the decades-long conflict that has affected international peace and security. Conversely, if the process fails, the world will continue to face militancy and terrorism with greater intensity. The twin towers disaster brought the world at odds. The surge of militancy on one hand and the US' 'immature' reaction to the 'war on terror' on the other hand has affected global peace adversely. The intensity of radicalization and extremism gained momentum and the pages of history began to get filled with inhuman incidents of airstrikes or suicide attacks (After 9/11: Global effects of the 'war on terror', 2011). 
There is no doubt that Afghan soil has become a breeding ground for terrorist activities across the globe and is a haven for transnational terrorist groups and activists. Militants fleeing from Iraq, Yemen and Syria have based themselves in Afghanistan and actively conduct militia activities under the patronage of intra-Afghan groups (Vestenskov \& Hasan, 2018; Shinn \& Dobbins, 2019). The ISKP has emerged as a potential threat to regional cum international peace and security (Jadoon, Jahanbani, \& Willis, 2018; Rahim \& Nordland, 2018). On the other hand, the US is publically proclaiming that it has succeeded in wiping out the menace of terrorism in Afghanistan and all the militant groups have either been rooted out or eradicated. But the evidence in Afghanistan does not support these claims. In 2018, the causalities in Afghanistan are the highest since the conflict started. In just four years of the Ghani regime, more than 45000 security personnel sacrificed their lives (Afghanistan's Ghani says 45,000 security personnel killed since 2014, 2019). The ongoing critical situation in Afghanistan forced the US to revisit its policy of 'war' and the Trump government decided to initiate peace talks with the Taliban and other stakeholders.

The US with the help and cooperation of Pakistan managed to arrange the peace talks with the Taliban representatives with Doha as the venue because it is neutral ground acceptable to both. 'The [cooperation between] Pakistan and [the] the US revisited policies on Afghanistan and has rekindled the hope of resolution of the protracted Afghan conflict that has only brought misery and despondency to the region,' to quote Pakistan's Foreign minister Shah Mehmood Qureshi responding to VOA (Gul, 2019).

During the talks, the US is managing to consolidate guarantees from the Taliban that the soil of Afghanistan will never be used for any transnational terrorist activity and they will never develop ties with any militant group in the future, whereas the Taliban has stressed that the US-led coalition force is evacuated from the country and that a representative government is instituted in Kabul. Both the sides are moving closer and observers believe that the 'ice has broken' (Constable, Ryan, \& Sonne, U.S., Taliban move closer to deal on American troop exit, 2019). If all the stakeholders succeed in reaching a workable agreement then the 18 years long war will end and Afghanistan will embark on a path of peace and stability. The world will also benefit from the cessation of hostilities. However, it depends on how sincere the stakeholders are and how they chalk out the post-US withdrawal arrangement.

It is pertinent to mention that stakeholders should minutely analyze the outcomes of the post-Soviet withdrawal and realize that they must rely only on indigenous sources to secure their interests and formulate an inclusive agreement. This will decide whether Afghanistan plunges into another conflict or settle on an era of lasting peace and stability that will promote regional connectivity. Depending on their stakes both in peace and war, neighbors and regional actors can be expected to be either facilitators or spoilers of the peace process (Khattak D., 2019).

The ray of hope that 'peace will win' is prevailing in the ongoing Doha talks. The evacuation of the US troops and the guarantee of the Taliban to disassociate themselves from terrorist groups will open new avenues towards establishing lasting regional peace and stability. Then the stakeholders will be able to turn their attention to work for the socio-economic uplift of the Afghans and the long-prevailing militancy will come to an end.

\section{Mainstreaming of Taliban}

During the last 18 years of war, the Taliban have succeeded in showing their power and strength even in the highly fenced and militarily secured areas of Afghanistan. They have dramatically changed the pattern of violence in recent years (Azami, Afghanistan war: What could peace look like?,2019). The US with the help of the world community could not succeed in wiping them off the soil of Afghanistan. However, the US did have several successes in dismembering them, but the main problem for the US-led troops was that they would invariably recruit and bounce back. Thus the Taliban was a continuous threat to the peace and security of Afghanistan. After decades of war, the US realized that they had to engage the Taliban on the table for peace talks and hence, acknowledge their legitimacy (Taking Stock of the Taliban's Perspectives on Peace, 2020); (Thomas, Afghanistan: Background and U.S. Policy: In Brief, 2019). On the other hand, the Taliban have become aware that war leads to nothing but misery and ruination. Under the facilitation of Pakistan, both sides realized the importance of negotiating peace and initiated the marathon talks in Doha.

The success of the peace talks depends upon the post-USA withdrawal constitutional arrangements and mainstreaming the Taliban into the political system. No government in Kabul will be effective without the support and proper share of power to the Taliban in the upcoming setup. The incumbent Kabul government is rapidly losing its territorial grip on far-flung areas whereas the Taliban is managing to increase its territorial grip.

The long-standing Afghan war had excluded the Taliban from mainstream politics. Thus they focused on their military strength and left political involvement unaddressed. Through the current negotiation, the US wants to bring the Taliban back into politics and force them to act as a political entity rather than militarily. The Taliban had shown their reservations over the existing political setup and constitutional power divisions. They stressed on reframing the constitution and include Islamic provisions. 
The Doha talks have rekindled the hope that the Taliban may be brought into mainstream politics and that they will actively participate in the future political setup of Afghanistan. Proper accommodation in the Kabul government is the only way to activate the Taliban politically and disengage them from militant activities.

\section{CONCLUSION}

The ongoing Doha US-Taliban peace talks generate a ray of hope that in the coming days, the decades-long Afghan war will end and a new chapter of peace, security, and economic stability will begin with a firm commitment that the soil of Afghanistan will never be used for terrorist activities against any state. However, it depends on what arrangements and the terms of the agreement the stakeholders propose during the talks. The end of the war and a conflict-free Afghanistan will bring regional peace and economic stability. The stakeholders should focus on the problems being faced by the nation in order that they do not revert to intra-Afghan conflict and ruinous war again. The regional and international actors should pursue their interests without using the soil of Afghanistan for seditious activities in rival countries. Blame game and proxy wars should be stopped.

Post-US Afghanistan requires modernization, enlightenment, tolerance, freedom, and liberty. The evils of illiteracy and radicalization should be addressed in a sophisticated and workable manner keeping in view the nature and customs of the societal setup. All the Afghan ethnic-regional groups should be provided equal opportunities to participate in the political setup.

If post-USA Afghanistan is characterized by a low level of modernization, enlightenment, and socio-political development, that is concrete evidence that the Kabul government has been ineffective in exercising control in far-flung areas. It should be borne in mind that ethnolinguistic and regional complexities provide convenience and ready to exploit fault lines. On the other hand, flexible and accommodative agreements with the consensus of all the stakeholders will pave a way to bring sustainable peace, stability, and security in Afghanistan and the region.

\section{LIMITATIONS OF THE STUDY}

The research is limited to analyze the expected hurdles and obstacles which can choke the Doha-based peace process in Afghanistan. The research suggests viable solutions to tackle the situation.

\section{IMPLICATION OF THE STUDY}

The current study will be helpful to policymakers, regional and international actors in devising conducive and viable policies to keep all the hurdles aside and make it sure to prevail the sustainable peace in Afghanistan.

\section{AUTHORS' CONTRIBUTION}

Mian Muhammad Azhar: Devised the main idea and wrote the paper.

Muhammad Waris: Collected relevant data.

Ali Shan Shah: Framed research design.

Abdul Basit: Analysed the data.

Zil-i-Huma Rafique: Edited the manuscript.

\section{REFERENCES}

1. Afghanistan Pledges October date for parliamentary election. (2018, April 1). Retrieved July 20, 2020, from https://www.reuters.com/article/us-afghanistan-election-idUSKCN1H810L

2. Afghanistan: Background and U.S. Policy in Brief. (2019, January 16). Retrieved May 10, 2020, from https://www.everycrsreport.com/files/20190116_R45122 b891ce4095f1e46bc13b657a94951 84bf6075e54.html

3. Afghanistan: Civilian deaths at record high in 2018 - UN. (2019, February 24). Retrieved November 26, 2020, from bbc.com: https://www.bbc.com/news/world-asia-47347958

4. Afghanistan's Ghani says 45,000 security personnel killed since 2014. (2019, January 25). Retrieved May 6, 2019, from www.bbc.com: https://www.bbc.com/news/world-asia-47005558

5. Afghanistan Presidential Rivals Strike Power-sharing Deal to End Stand off. (2020, May 17). Retrieved June 20, 2020, from telegraph.co.uk: https://www.telegraph.co.uk/news/2020/05/17/afghanistan-presidential-rivals-strikepower-sharing-deal-end/

6. After 9/11: Global effects of the 'war on terror'. (2011, September 9). Retrieved April 22, 2019, from https://www.b bc.com/news/world-14844727 
7. Ahmadzai, M. M. (2017, September 17). Afghanistan and regional cooperation: Opportunities and impediments. Retrieved February 18, 2019, from http://www.afghanistantimes.af/ afghanistan-and-regional-cooperationopportunities-and-impediments/

8. Azami, D. (2018, April 2). Is Russia arming the Afghan Taliban? Retrieved January 21, 2019, from https://www.bbc.com/news/world-asia-41842285

9. Azami, D. (2019, July 14). Afghanistan war: What could peace look like? Retrieved July 20, 2019. from https://www.bbc.com/news/world-asia-47733079

10. Bew, J., Evan, R., Frampton, M., Porges, M., \& Neumann, P. (2013). Talking to the Taliban Hope over History? London: The International Centre for the study of Radicalisation and Political Violence (ICSR).

11. Chalk, L. H. (2012). India's and Pakistan's Strategies in Afghanistan: Implications for the United States and the Region. Pittsburgh: Centre for Asia Pacific Policy.

12. Chaudhuri, R., \& Shende, S. (2020, June 20). Dealing With the Taliban: India's Strategy in Afghanistan After U.S. Withdrawal. Retrieved June 24, 2020, from https://carnegieindia.org/2020/06/02/dealing-with-taliban-india-sstrategy-in-afghanistan-after-u.s.-withdrawal-pub-81951

13. Cordesman, A. H. (2020). Afghanistan: No Real Peace Process and No Progress Towards Definite Real Peace. Washington D.C.: Center for Strategic \& International Studies.

14. Constable, P., \& Salahuddin, s. (2018, October 18). U.S. commander in Afghanistan survives deadly attack at governor's compound that kills top Afghan police general. Retrieved March 12, 2019, from https://www.washingtonpost.com/world/asia_pacific/gunfire-erupts-in-afghan-governors-compound-after-meetingwith-us-commander/2018/10/18/109fc5e0-d2ce-11e8-b2d2-f397227b43f0_story.html?utm term=.9529692d0958

15. Constable, P., Ryan, M., \& Sonne, P. (2019, January 28). U.S., Taliban move closer to deal on American troop exit. Retrieved June 5, 2019, from https://www.washingtonpost.com/world/asia_pacific/afghan-president-calls-for-directtalks-with-taliban-us-tentatively-agrees-on-framework-that-could-lead-to-troop-withdrawal/2019/01/28/23ecbaba22f9-11e9-81fd-b7b05d5bed90 story.html?noredirect=on\&utm term

16. Farr, G. (2020, April 6). The peace agreement and its problems. Retrieved February 10, 2021, from www.e-ir.info: (https://www.e-ir.info/2020/04/06/the-afghan-peace-agreement-and-its-problems/)

17. Felbab, D. V. (2016). The Afghanistan Challenge: US Troops Withdrawal and the Stability of Afghanistan. In S. S. Aneel, Evolving Situation in Afghanistan: Role of Major Powers and Regional Countries (p. 177). Islamabad: Islamabad Policy Research Institute.

18. Gul, A. (2019, July 16). Pakistan-US Cooperation 'Has Rekindled Hope' for Afghan Peace. Retrieved July 19, 2019, from https://www.voanews.com/south-central-asia/pakistan-us-cooperation-has-rekindled-hope-afghan-peace

19. Haidari, M. A. (2017, June 28). For Peace in Afghanistan, Listen to Afghans. Retrieved April 14, 2019, from https://thediplomat.com/2017/06/for-peace-in-afghanistan-listen-to-afghans/

20. Hossaini, A. Y. (2020, April 30). Looking ahead to Intra-Afghan Negotiations: A scrutiny of different political groups' plans for peace. Retrieved May 19, 2020, from https://www.afghanistan-analysts.org/en/reports/war-andpeace/intra-afghan-negotiations-a-look-at-various-afghan-peace-plans/

21. Hussain, Z. (2019, January 30). Talking Afghan Peace. Retrieved June 18, 2019, from https://www.dawn.com/news/1460713

22. Idrees, M., Rehman, A. u., \& Naazer, M. A. (2020). Afghan Peace Process and the Role of Pakistan in Engaging the Stakeholders. Liberal Arts and Social Sciences International Journal, 3(2), 20-34.

23. India using Afghan soil for terrorism in Balochistan says Interior Minister. (2017, November 16). Retrieved March 25, 2019, from https://www.geo.tv/latest/167895-india-using-afghan-soil-for-terrorism-in-baluchistan-says-interiorminister

24. Interpreting the U.S. Talks with the Taliban. (2019, January 29). Retrieved July 11, 2019, from https://www.crisisgroup.org/asia/south-asia/afghanistan/interpreting-us-talks-taliban

25. Jadoon, A., Jahanbani, N., \& Willis, C. (2018). Challenging the ISK Brand in Afghanistan-Pakistan: Rivalries and Divided Loyalties. CTC Sentinel, 11(4), 1-39.

26. Jami, M. (2020). Intra-Afghan Peace Talks: A Channel to Peaxe. Glocality, 3(1), 1-16. https://doi.org/10.5334/glo.18

27. Johnson, C. G. (2016). The Rise and Stall of the Islamic State in Afghanistan. Washington D.C.: US Institute of Peace.

28. Kaura, V. (2018). Understanding the Complexities of the Afghan Peace Process. Observer Research Foundation, April, 1-30.

29. Kazmi, S. S. (2015). Afghan Peace Process: Prospects and Challenges for Pakistan. Journal of Security and Strategic Analysis, 119-143.

30. Kenfall, J. (2002). The Incalculable Risk: How the World Trade Center Disaster Accelerated the Evolution of Insurance Terrorism Exclusion. Richmond Law Review, 36(2), 569-596. 
31. Khan, A. (2016). Prospects of Peace in Afghanistan. Strategic Studies, 36(1), 18-46.

32. Khattak, D. (2019, February 14). Without Regional Cooperation, Afghan Peace Will Remain Elusive. Retrieved July 2, 2019, from https://thediplomat.com/2019/02/without-regional-cooperation-afghan-peace-will-remain-elusive/

33. Khattak, Z. U. (2018, November 12). Afghanistan Peace Process, Challenges and Opportunities. Retrieved May 12, 2019, from http://blogs.dunyanews.tv/23629/

34. Malkasian, C. (2020, March/April 2020). How the Good War Went Bad, America's Slow-Motion Failure in Afghanistan. Retrieved November 26, 2020, from https://www.foreignaffairs.com/articles/afghanistan/2020-0210/how-good-war-went-bad

35. Mashal, M. (2020, May 17). Afghan Rivals Sign Power-Sharing Deal as Political Crisis Subsidise. Retrieved May 22, 2020, from https://www.nytimes.com/2020/05/17/world/asia/afghanistan-ghani-abdullah.html

36. Mashal, M. (2020, February 29). Taliban and U.S. Strike Deal to Withdraw American Troops From Afghanistan. Retrieved August 1, 2020, from https://www.nytimes.com/2020/02/29/world/asia/us-taliban-deal.html

37. Miller, L. E., \& Blake, J. S. (2019). Envisioning a Comprehensive Peace Agreement for Afghanistan. Santa Monica: RAND Corporation. https://doi.org/10.7249/RR2937

38. Pandey, S., \& Sareen, S. (2020). Between a Republic and an Emirate: The Future of Afghanistan. Observer Research Foundation.

39. Qazi, S. (2019, August 13). 'Peace deal is near': What we know so far about US-Taliban talks. Retrieved April 10, 2020, from https://www.aljazeera.com/news/2019/8/13/peace-deal-is-near-what-we-know-so-far-about-us-talibantalks

40. Qazi, S. (2019, June 29). US-Taliban talks for peace in Afghanistan: What we know so far. Retrieved July 19, 2019, from https://www.aljazeera.com/news/2019/05/taliban-talks-peace-afghanistan-190510062940394.html

41. Rahim, N., \& Nordland, R. (2018, August 1). Taliban Surge Routs ISIS in Northern Afghanistan. Retrieved March 18, 2019, from https://www.nytimes.com/2018/08/01/world/asia/afghanistan-taliban-isis.html

42. Robin, M. (2002, March). Who Is Responsible for the Taliban? Retrieved November 18, 2019, from https://www.washingtoninstitute.org/policy-analysis/view/who-is-responsible-for-the-taliban

43. Sales, N. A. (2019). Countery Reports on Terrorism 2019. Washington D.C.: State Department.

44. Schmeidl, S. (2016). The Contradictions of Democracy in Afghanistan: elites, elections and 'people's rule" Post 2001. Conflict, Security \& Development, 16(6), 575-594. https://doi.org/10.1080/14678802.2016.1248427

45. Shams, S. (2019, July 06). Intra-Afghan dialogue-end of war more likely than ever. Retrieved July 12, 2019, from https://www.dw.com/en/intra-afghan-dialogue-end-of-war-more-likely-than-ever/a-49499704

46. Sheikh, M. K., \& Khan, A. (2019). Prospects of Settlement with the Afghan Taliban Exit, Peace and Governance from the Taliban Perspective. Copenhagen: Danish Institute for International Studies.

47. Shinwari, A. J. (2019). An Assessment of Peace Negotiation between the United States Government and the Taliban Insurgent Group, 2001-2018. Baltimore, Maryland: John Hopkins University.

48. Sheikh, M. K., \& Greenwood, M. T. (2013). Taliban Talks: Past, Present and Prospects for the US, Afghanistan and Pakistan. Copenhagen: DIIS: Danish Institute for International Studies.

49. Shinn, J., \& Dobbins, J. (2019). Afghan Peace Talks: A Primer. Santa Monica: Rand Corporation.

50. Taking Stock of the Taliban's Perspectives on Peace. (2020).Brussels: International Crisis Group.

51. Tariq, M. (2020). US-Afghan Talks: Myths and Realities. Global Political Review, V(I), 104-111. https://doi.org/10.31703/gpr.2020(V-I).12

52. Their, A. (2019, September 16). What are the Prospects for Power-Sharing in the Afghan Peace Process? Retrieved June 18, 2020, from https://www.usip.org/publications/2019/09/what-are-prospects-power-sharing-afghan-peaceprocess

53. Thomas, C. (2019). Afghanistan: Background and U.S. Policy: In Brief. Wahington, D.C.: Congressional Research Service.

54. Tronc, E., \& Nahikian, A. (2018). Fragile Future: The Human Cost of Conflict in Afghanistan. Harvard Humanitarian Initiative. https://doi.org/10.2139/ssrn.3291982

55. Twenty-second report of the Analytical Support and Sanctions Monitoring Team submitted pursuant to resolution 2368 (2017) concerning ISIL (Da'esh), Al-Qaida and associated individuals and entities. (2018). Washington DC: UNO.

56. United States Signs Agreement with the Taliban, but Prospects for Its Full Implementation Remain Uncertain. (2020). American Journal of International Law, 114(3), 529-538. https://doi.org/10.1017/ajil.2020.45

57. Vestenskov, D., \& Hasan, R. (2018). Approaching Peace Talks in Afghanistan: Stakeholders, Challenges and Prospects. London: Policy Brief-Royal Danish Defence College.

58. Wahdatyar, H. (2017, February 14). 4 Reasons Russia Increasingly Favors the Taliban in Afghanistan. Retrieved January 22, 2019, from https://thediplomat.com/2017/02/4-reasons-russia-increasingly-favors-the-taliban-inafghanistan/ 